fertilization with plonvit active. Rom. Biotechnol. Lett., 2014, 19, 9510-9516.

47. Panayotova, G. D., Bozhanova, V. Z., Kostadinova, S. S., Valkova, N. K. and Almaliev, M., Response of durum wheat (Triticum durum Desf.) cultivar progress to foliar feeding. Agric. Food, 2014, 2, 288-297.

48. Bulut, S., Öztürk, A., Karaoğlu, M. M. and Yildiz, N., Effects of organic manures and non-chemical weed control on wheat. II. Grain quality. Turk. J. Agric. For., 2013, 37, 271-280.

49. Ralcewicz, M., Knapowski, T., Kozera, W. and Barczak, B., Technological value of 'Zebra' spring wheat depending on the nitrogen and magnesium application method. J. Cent. Eur. Agric., 2009, 10, 223-232.

50. Biel, W. and Maciorkowski, R., Assessing nutritional value of grains of selected wheat cultivars. Food Sci. Technol. Qual., 2012, 2, 45-55.

51. Podolska, G. and Sułek, A., Quality of wheat grain produced in Poland and the UE. Pam. Put., 2003, 132, 363-369.

ACKNOWLEDGEMENTS. Publication carried out with the use of instruments bought in the framework of programme 'Development of Stage 2 of Regional Centre for Innovativeness' the European Fund for Regional Development in the framework of the Regional Operation Programme of Kuyavian-Pomeranian for 2007-13.

\section{Challenges of hill farming due to crop-raiding by wild pigs in the Indian Himalayan region}

\author{
Latika Pandey $^{1, *}$, Ayyanadar Arunachalam ${ }^{1}$ and \\ Namita Joshi ${ }^{2}$ \\ ${ }^{1}$ Task Force on Himalayan Agriculture, Indian Council of Agricultural \\ Research, Krishi Anusandhan Bhawan-II, New Delhi 110 012, India \\ ${ }^{2}$ Gurukul Kangri Vishwavidyalaya, Haridwar, Jagjeetpur, \\ Haridwar 249 404, India
}

The human societies living in the Himalayas are traditionally known for their symbiotic relationship with their surrounding ecosystem. With changing time and climatic conditions, this relationship is also transforming. One of the crucial examples of this transformation is the interaction between human and wild animals, that a few of the Himalayan villages have moved from 'co-sustenance' to 'conflict'. The agribased villages situated adjoining the forest area are experiencing recurrent incidences of crop raiding by wild pigs. These raidings have emerged out as a noticeable threat to the existing agrobiodiversity of the area. Hence, plausible solutions to keep away the

*For correspondence. (e-mail: latikalata237@gmail.com) crop raiders with special emphasis on the wild pigs are the need of the hour.

Keywords: Agriculture, crop raiding, Himalayas, wild pig.

RECENT years have witnessed increasing incidences of human and wild animal conflicts, particularly in those villages that are neighbouring wilderness ${ }^{1,2}$. Reportedly, blackbuck in Gujarat has caused a loss of $48,600 \mathrm{~kg}$ of sorghum in a single season in two villages worth Rs $29,000$ (US $\$ 558)^{3}$. From carnivores like leopard and tiger that have wider habitat range to the smaller ones including wild pigs, porcupine, rabbits, mice and rats cause damage to human upon sudden encounters ${ }^{4-6}$. In the plains of Uttarakhand, other than wild pig (Sus scrofa), there are animals which damage crops like sambhar (Rusa unicolor), nilgai (Boselaphus tragocamelus), cheetal (Axis axis) and elephant (Elephas maximus). Of these, wild pig and nilgai enter the fields which are farther from the forest ${ }^{7}$. A case study of Bilaspur district of Sutluj valley in the outer hills of the Himalaya depicted that the major menace for crop depredation was wild rhesus macaque, followed by wild pig and then rodents. The study also reported a considerable increase in weed population like Anagallis arvensis and Lantana camara ${ }^{8}$.

The Himalayan agro-ecosystems are vulnerable to man-animal interface that cause causalities as well as crop damage. In our efforts to reduce man-animal conflict, particularly in vulnerable areas, it is important to take stock of the site characteristics and human vulnerabilities and understand the dynamics and challenges in doing agriculture under exorbitant threats posed by the crop-raiders. We surveyed two villages in the forested neighbourhood of Almora district in Uttarakhand and documented the crop raiders and their impact on cropping systems.

The present study was carried out in two adjacent villages, Dantola $\left(29^{\circ} 51.266^{\prime} \mathrm{N}\right.$ and $\left.79^{\circ} 22.962^{\prime} \mathrm{E}\right)$ and Mahatgaon $\left(29^{\circ} 51.608^{\prime} \mathrm{N}\right.$ and $\left.79^{\circ} 22.507^{\prime} \mathrm{E}\right)$ of Kumaun Himalaya in the Almora district of Uttarakhand where the altitude ranges from 1010 to $1106 \mathrm{~m}$. The region receives an annual rainfall of $862.8 \mathrm{~mm}$. Agriculture is the backbone of the region, as more than $50 \%$ of the people are dependent on it for sustaining their livelihood. Total forest cover of the district is $1583 \mathrm{sq} . \mathrm{km}$ which is around $50 \%$ of the total area of the district ( 3144 sq. km), indicating the importance of forests in the lives of hill people? .

Both the villages are situated adjoining the forest area. Hence many wild animals like leopard, wild pigs, deer, fox, apes and monkeys are often found roaming in the villages. Leopard, deer and wild boar are generally seen at nights, while the monkeys and apes are abundant during day time in these villages. Fox are also seen anytime of the day. Villagers traditionally visit the forest to 


\section{RESEARCH COMMUNICATIONS}

collect fuelwood, grasses and for livestock grazing, mainly the goats. All these make the villagers vulnerable to human-wildlife conflict.

The study area gets a good sunshine along with sufficient amount of rainfall all through the year ${ }^{10}$. However, water scarcity is reported during the summers (MayJune). The available arable land is cultivated all around the year, both in rabi (October/November to April/May) and kharif (May/June to September/October) seasons. Major rabi crops are Triticum aestivum L., Hordeum vulgare L., Lens culinaris Medik., Linum usitatissimum L., Brassica juncea (L.) Czern. and Coss., Brassica campestris L., Trifolium alexandrinum L. Likewise, the major kharif crops are Oryza sativa L., Eleusine coracana (L.), Sorghum vulgare (L.) Pers., Glycine max (L.) Merr., Vigna mungo (L.) and Macrotyloma uniflorum (Lam.) verdc. The land is kept fallow for 15-20 days at the end of every cropping season. Apart from this, vegetables and spices are grown in the kitchen gardens. Major fruiting trees found in the village are mango, walnut, guava, pear and

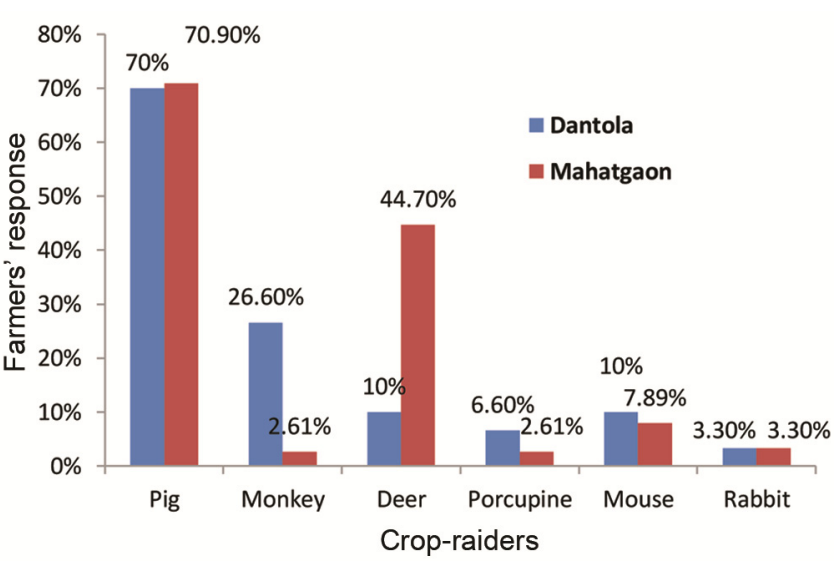

Figure 1. Farmers' perception on most damaging animals for crops.

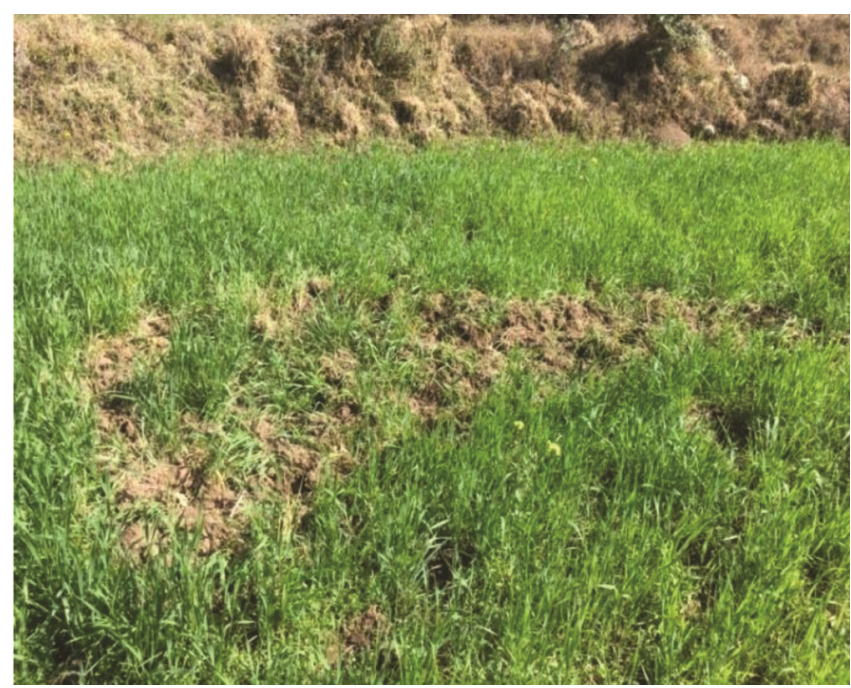

Figure 2. Uprooted wheat crop by wild boar. litchi. A door-to-door survey was conducted in the village with the help of a structured and pre-tested questionnaire during 2017 and information regarding the crop raiding by wild-pig was gathered by covering $68 \%$ households ( 1 respondents from each house) from Dantola and 53\% households (1 respondents from each house) from Mahatgaon village.

The agriculture in the study area is in transition state. Earlier, agriculture was fully traditional, but now-a-days farmers have started using chemical fertilizers, new crop varieties along with a shift from mixed cropping towards monocropping. The main reason for this shift is attributed to low productivity of the hill agro-ecosystem as they are ecologically challenged. In addition, ingression of wild animals and shortage of agricultural labours have also digressed the farmers from doing agriculture. While surveying the villages in the hill districts of Almora, Uttarakhand, it was observed that wild pig (Sus scrofa) emerged as a major menace, as $70 \%$ of the villagers named it as crop raider (Figure 1). Apart from wild boar, deer, porcupine and mouse also raid the crops (cereals and vegetables). This, inadvertent scenario has stressed the farmers to an extent that income from agriculture is meagre and so is not a viable economic option anymore.

The aggression of wild pig is experienced in the crop fields throughout the crop cycle. The farmers revealed that when the crop is young, the wild pigs from the forested neighbourhood come and destroy the crops by tilling the soil using its teeth in search of food (Figure 2). When the crop is ready for harvest, these animals destroy the crop by eating the grains and also by random movement across the fields (Figure 3 ). Kumar et al. ${ }^{7}$ found that the crop raiding by ungulates and wild elephants was higher during seedling stage in comparison to maturity stage. Wild pigs are known to injure or kill human beings in many of the Indian States in the past, out of which maximum causalities occurred in the forest $(73.8 \%)$,

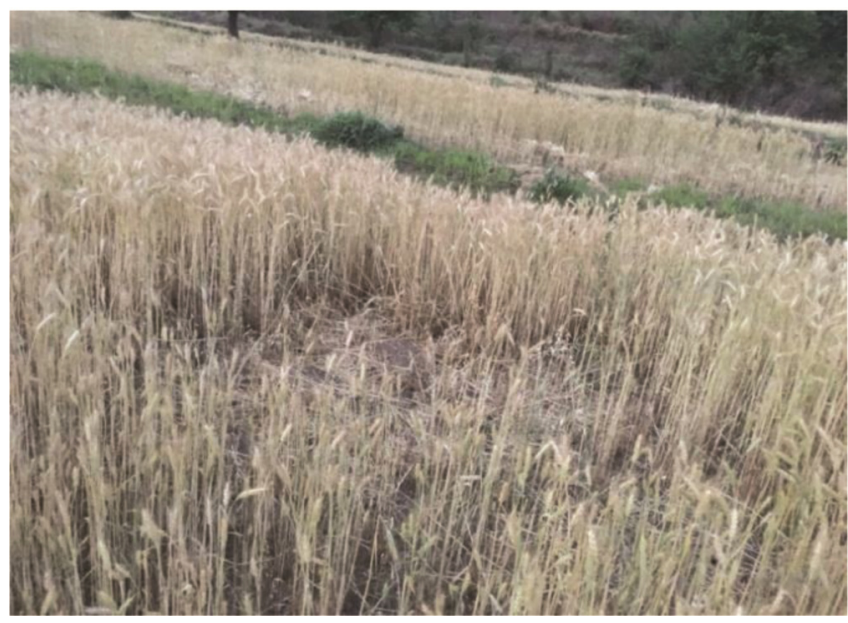

Figure 3. Crop raiding by wild boar during maturity stage of wheat crop. 

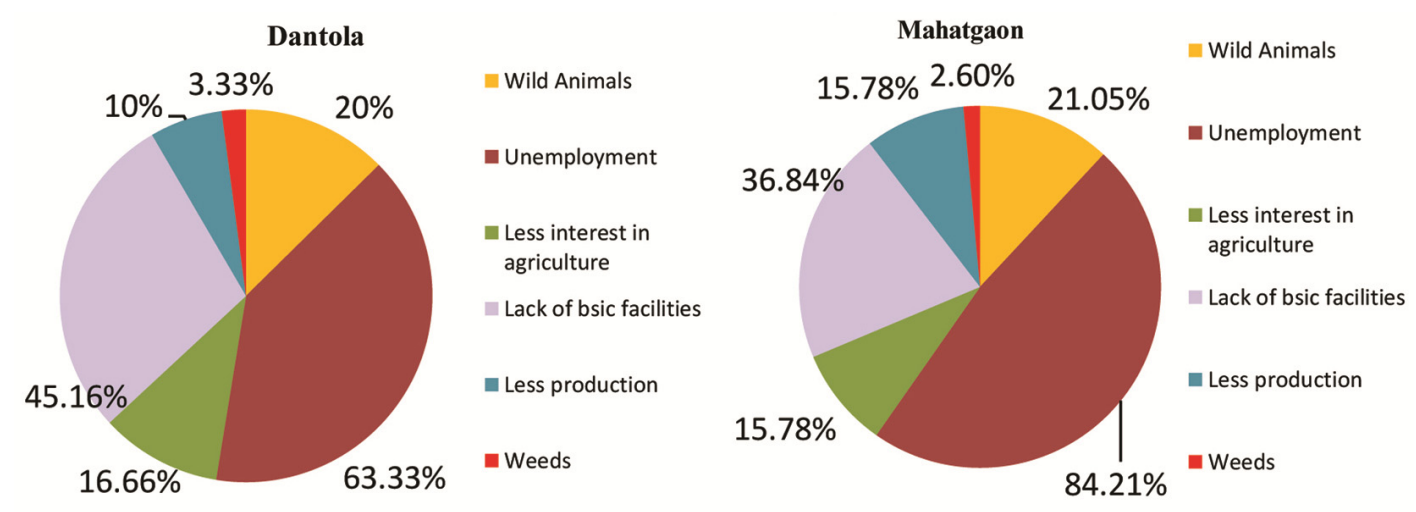

Figure 4. Causes of migration in the study villages.

Table 1. Crop species facing challenges according to the villagers

\begin{tabular}{ll}
\hline Crop species & \multicolumn{1}{c}{ Reason for decrease in area } \\
\hline Finger millet & Wild pig, lack of labour \\
Lentil & Wild pig \\
Garlic & Wild pigs, lack of water availability for irrigation \\
Onion & Wild pigs, lack of water availability for irrigation \\
Potato & Wild pig, porcupine \\
Ginger & Wild pig \\
Brinjal & Lack of water availability for irrigation, termite \\
Chilli & Porcupine (before fruiting) \\
Fenugreek & Porcupine \\
Barseem & Rabbit \\
Gram & Wild pigs \\
Maize & Wild pigs, fox \\
Capsicum & Lack of water availability for irrigation \\
Lady's finger & Lack of water availability for irrigation \\
Pea & Lack of water availability for irrigation, birds \\
Jowar & Birds \\
Cereals (wheat & Field mice and rats, wild pig \\
$\quad$ and paddy) & \\
\hline
\end{tabular}

followed by agriculture fields $(21.7 \%)$ and a few in the villages $(4.5 \%)^{2}$.

Another challenge in these villages is rodents like 'field mice' (Mus spp.) and 'rats' which cripple the matured crop particularly cereals, from the collar region and eat away the grains. In the kitchen gardens, porcupine is the major menace affecting the vegetable production system of particularly potato, young chilli and fenugreek plants. Apart from this, rabbit and deer also visit the crop fields occasionally and graze the green crop. This results in the reduction of cropped area as well as crop diversity (Table 1). Finger millet (madua) has higher nutritional content than rye, oats and barley and is a rich source of dietary fibre (18\%), phytates $(0.48 \%)$, protein $(6-13 \%)$, minerals $(2.5-3.5 \%)$, calcium $(0.34 \%)$ and phenolics $(0.3-3 \%)^{11}$ was widely cultivated and consumed earlier in the area. However, due to crop raiding by wild pigs, the production declined and now only a few farmers are growing this crop. Crops like black sesame (black til), amaranthus (chaulai), Vigna angularis (raiyans) and Echinochloa frumentacea (madira) have completely vanished from the cropping system of the villages, adding to the loss of agrobiodiversity in the Kumaun Himalaya.

Apart from crop raiding by wild animals, lack of employment opportunities and basic facilities has forced many villagers to abandon agriculture and migrate to towns and cities resulting in empty houses in the villages $^{12}$. Currently, $18.18 \%$ of the households in the village of Dantola and 33\% in Mahatgaon are empty. Migration being a substantial phenomena in the state, the economy of Uttarakhand is also called as 'money order economy ${ }^{13}$. Figure 4 indicates that the three important factors influencing migration are unemployment, lack of basic facilities (quality education, health and transport, etc.) and wild animals. Simultaneously, this has also led to the degradation of agrobiodiversity, because of which many landraces have been $\operatorname{lost}^{14,15}$. As a result, agriculture lands are left fallow, contributing to reduced production. Further, weed invasion is pronounced in the fallow lands. For example, Lantana camara has rampantly increased both in crop fields and forests ${ }^{16}$. Due to the invasion of weeds and bushes, these lands become solitary, which further provides shelter to the wilderness, thus harbouring the wild animals nearer to the village areas.

As the wild pig is a nocturnal animal, local people encounter these uninvited guests only after mid-night. Depending on seasonal variation, the wild pigs emerge out as early as $7-8$ p.m. in the winters and $8-9$ p.m. in the summers. They are seen roaming in the village paths and agricultural fields. Many studies have reported the causalities caused by wild pig to the mankind ${ }^{2,17,18}$. Nonetheless, the wild pig has become a major agricultural pest for villagers in the study area. As the wild pigs were observed to raid finger millet, potato, colocasia, lentil, etc., the local farmers have started growing these crops in a very limited area or restricted to the kitchen gardens, 


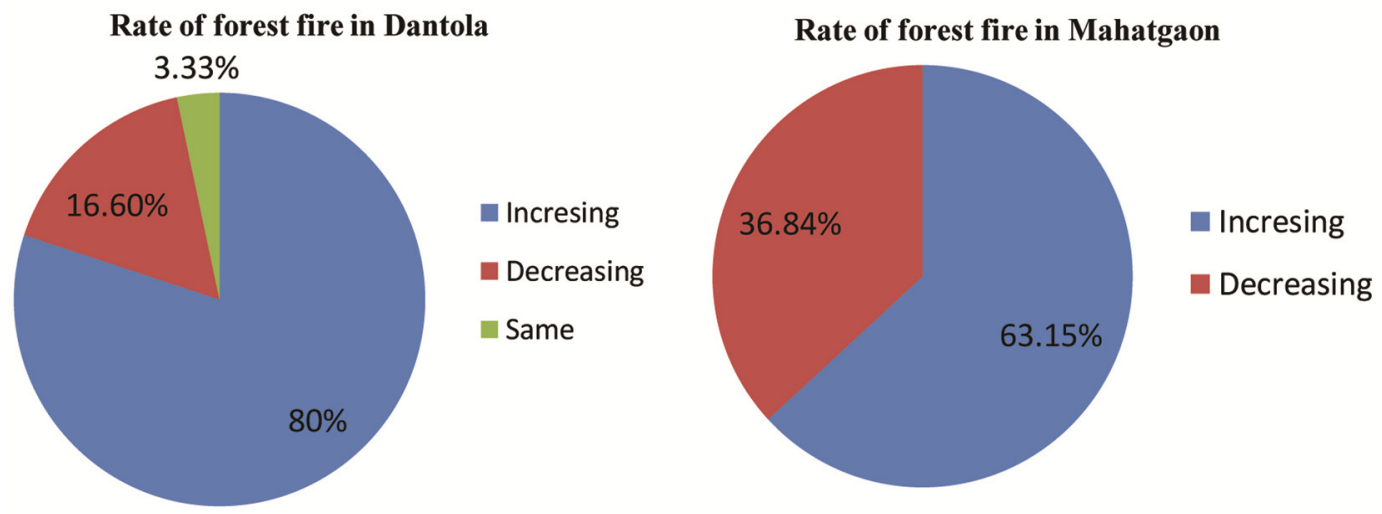

Figure 5. Peoples' perception about the rate of forest fire during the past few years in the study villages.

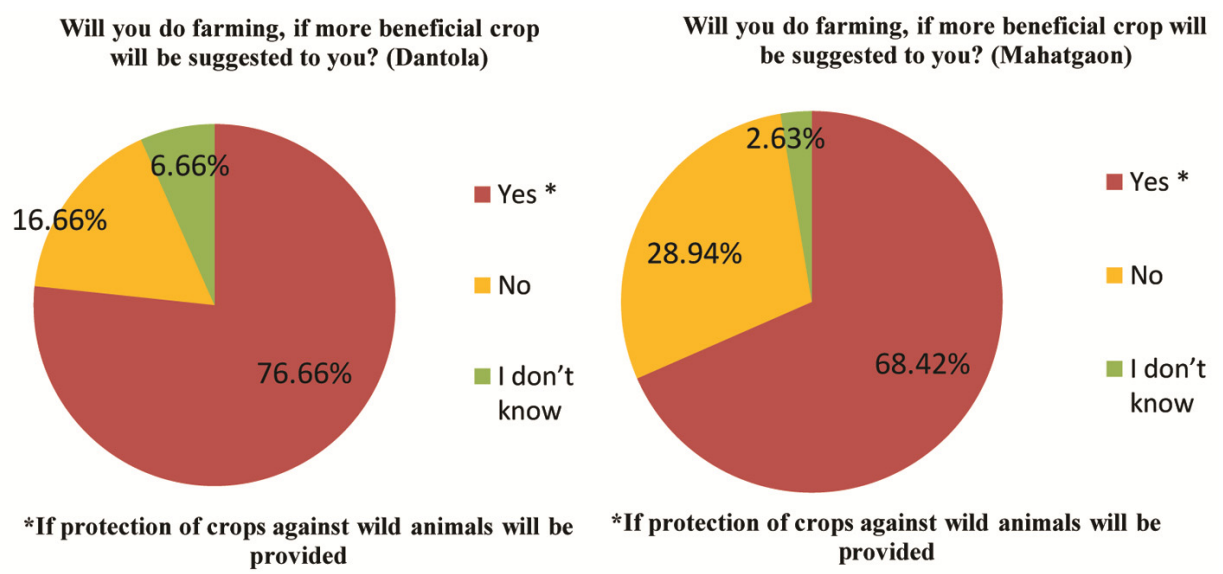

Figure 6. Peoples' perception regarding the introduction of more beneficial crop.

due to which these wild pigs have started feeding on other crops like soybean, bhatt (black soybean), paddy and wheat, etc. This poses a new and recurrent challenge for farmers as it affects the overall yield.

Earlier, people used to place scare-crows to repel animals and birds from the field. But now, this technique has also become useless, as the animals have developed resistance over it. The villagers also opined that in earlier days, the youth groups used to visit the fields at night for safe-guarding. Activities like beating drums and making scary noises were popular to repel the wild animals like boar, fox, leopard, etc. Presently, the percentage of youth is poor in the villages, as they all have migrated either for education or for better livelihoods. Nevertheless, the use of firecrackers is being adopted to scare away nocturnal animals and monkeys and apes during the day.

It was also observed that people used thorny bushes on the bunds of the crop fields like ber (Ziziphus sp.), kilmoda (Berberis aristata), hisalu (Rubus ellipticus), arandi (Ricinus communis), etc. all of which use to protect the fields from wild animals by acting like a natural barrier. Fruits of Ricinus communis are poisonous and were inten- tionally grown to drive away wild animals ${ }^{19}$, besides its medicinal use by the villagers. These bushes also prevented soil erosion in terraces during the rains. Apart from this, a thorny tree, called Pyrus pashia (mehal) was also planted to keep away monkeys and apes from the field and to fence the susceptible crops ${ }^{20}$. Today, this traditional practice is lacking, as it could not be inherited naturally owing to education and enhanced human mobility away from the villages for income generation.

The villagers, particularly women, traditionally visit the neighbouring forest for grass, fuelwood and wild fruit collection. They used to cut the weeds and unwanted bushes in the forests that culturally facilitated the germination and growth of native flora, thus enabling the availability of feed resources in the wilderness. But today, a few villagers depend on the forest. Evidently, invasive weeds like Lantana camara flourished in the forest along with Bauhinia vaheli and other weeds ${ }^{21}$ affecting the regeneration of native flora and create resource crunch for fodder, that eventually drove the wild animals towards villages. Further, dense weeds also make the site vulnerable to fire (Figure 5). It was observed that the 
domestic livestock graze the vegetation in wilderness areas which makes the ecology of both ecosystems susceptible to weeds, as they carry over the seeds criss-cross, i.e. forest to cropfields and also from crop fields to forest.

In general, it was observed that villagers were not getting utilizable produce commensurating to their labour and other input. Around $16.66 \%$ of farmers in Dantola and $28.94 \%$ in Mahatgaon expressed less interest in pursuing agriculture, even if more beneficial cash crop was suggested to them. Nevertheless, there are $76.6 \%$ and $68.42 \%$ farmers in Dantola and Mahatgaon respectively, who still want to pursue agriculture (Figure 6). This warrants strategic provision for protection of their crops and crop fields. Hence, plausible solutions to keep crop raiders at bay with special emphasis on the wild pigs are the need of the hour.

Despite various challenges like migration, crop-raiding by wild animals and changing climatic conditions in the Himalayas, agriculture has been a source of livelihood sustenance for the mountain societies. Protection of crops from different crop raiders is very important to conserve the agrobiodiversity in the Himalayan region. In this regard, it is worth considering the revival of traditional methods of restraining crop-raiding by growing plants that forbid animal attention. Further, new economically viable crops need to be screened for introduction in these affected areas that could reduce crop-raiding incidences. As an economic-mitigation strategy, enabling crop insurance against crop failure due to wild animal will also help in neutralizing the crop loss to vulnerable communities of the mountain in order to retain these people in agriculture.

1. Sam, M. K., Danquah, E., Oppong, S. K. and Ashie, E. A., Nature and extent of human-elephant conflict in Bia Conservation Area, Ghana. Pachyderm, 2004, 49-58.

2. Chauhan, N. P. S., Barwal, K. S. and Kumar, D., Human-Wild pig conflict in selected states in India and mitigation strategies. Acta Silv. Lignaria Hung., 2009, 5, 189-197.

3. Jhala, Y. V., Damage to sorghum crop by blackbuck. Int. J. Pest Manage., 1993, 39, 23-27.

4. Karanth, K. K., Gopalaswamy, A. M., Prasad, P. K. and Dasgupta, S., Patterns of human-wildlife conflicts and compensation: Insights from Western Ghats protected areas. Biol. Conserv., 2013, 166, 175-185.

5. Athreya, V., Odden, M., Linnel, J. D. C. and Krishnaswamy, J., A cat among the dogs: Leopard Panthera pardus diet in a human dominated landscape in western Maharashtra, India. Oryorys, 2016, 50, 156-162.

6. Rautela, P. and Karki, B., Impact of climate change on life and livelihood of indigenous people of higher Himalaya in Uttarakhand, India. Am. J. Environ. Protect., 2015, 3, 112-124.
7. Kumar, A., Bargali, H. S., David, A. and Edgaonkar, A., Patterns of crop raiding by wild ungulates and elephants in Ramnagar Forest Division, Uttarakhand. Hum.-Wildl. Interact., 2017, 11, 41-49.

8. Saraswat, R., Sinha, A. and Radhakrishna, S., A god becomes a pest? Human-rhesus macaque interactions in Himachal Pradesh, northern India. Eur J. Wildl Res., 2015, 61, 435-443.

9. Thukral, R. K. (ed.), Uttarakhand District Factbook ${ }^{\mathrm{TM}}$. In Almora District: Key Socio-Economic Data of Almora District, Uttarakhand, Datanet India Pvt Ltd, New Delhi, 2018, pp. 136-138.

10. Jain, S. K., Kumar, S. and Varghese, J., Estimation of soil erosion for a Himalayan watershed using GIS technique. Water Resour. Manage., 2001, 15, 41-54.

11. Chandra, D., Chandra, S., Pallavi and Sharma, A. K., Review of Finger millet (Eleusine coracana $(\mathrm{L}$.$) Gaertn): a power house of$ health benefiting nutrients. Food Sci. Hum. Wellness, 2016, 5, $149-155$.

12. Mamgain, R. P. and Reddy, D. N., Out-migration from the Hill Region of Uttarakhand: Magnitude, Challenges, and Policy Options. In Rural Labour Mobility in Times of Structural Transformation (eds Reddy, D. and Sarap, K.), Palgrave Macmillan, Singapore, 2017, pp. 209-235.

13. Kandari, P., Migration pattern and the increasing participation of females in the economy of hill rural areas: a study of Pauri district in Uttarakhand. IOSR. J. Human. Soc. Sci., 2013, 17, 27-33.

14. FAO, The State of the World's Plant Genetic Resources for Food and Agriculture, FAO, Rome, 1997, pp. 13-20.

15. Nautiyal, S., Bisht, V., Rao, K. S. and Maikhuri, R. K., The role of cultural values in agrobiodiversity conservation: a case study from Uttarakhand, Himalaya. J. Hum. Ecol., 2008, 23, 1-6.

16. Mandal, G. and Joshi, S. P., Invasion establishment and habitat suitability of Chromolaena odorata (L.) King and Robinson over time and space in the western Himalayan forests of India. J. AsiaPacific Biodiver., 2014, 7, 391-400.

17. Chauhan, N. P. S., Human casualties and agricultural crop raiding by wild pigs and mitigation strategies in India. In 8th European Vertebrate Pest Management Conference. Berlin, Germany, 26-30 September 2011, pp. 192-193.

18. Okano, I. et al., Penetrating anorectal injury caused by a wild boar attack: a case report. Wilderness and Environmental Medicine, 2018; https://doi.org/10.1016/j.wem.2018.02.007.

19. Milewski, L. M., Khan, B. S. and Khan, S. A., An overview of potentially life-threatening poisonous plants in dogs and cats. J. Vet. Emerg. Crit. Care, 2006, 16, 25-33.

20. Chauhan, P. P., Nigam, A. and Santvan, V. K., Ethnobotanical survey of trees in pabbar valley, Dist. Shimla, Himachal Pradesh. Life Sci. Leafl., 2014, 53, 38-52.

21. Khanduri, A., Biswas, S. and Vasistha, H. B., Forest invasive species assessment study in different village forests of Garhwal Himalaya. Int. J. Curr. Res. Rev., 2017, 9, 8-18.

ACKNOWLEDGEMENT. The work was supported by DST, Govt of India through Task Force on Himalayan Agriculture under the National Mission for Sustaining the Himalayan Ecosystem.

Received 13 August 2018; revised accepted 27 December 2018

doi: $10.18520 / \mathrm{cs} / \mathrm{v} 116 / \mathrm{i} 6 / 1015-1019$ 